\title{
Analisis Following to Followers Ratio Instagram Pada 5 Cafe Hits Di Kintamani, Bali
}

\author{
I Made Andi Kertha Yasa \\ STMIK STIKOM Indonesia \\ andikertha7@gmail.com
}

\begin{abstract}
Instagram is one of the social media that currently exists in the community. This application can be downloaded via cellphone, tablet, PC or can be opened directly through the official Instagram website. At the beginning of Instagram, the only features available were to share stories in the form of images and find Instagram friends. But along with its development, Instagram has undergone many changes, such as being able to upload videos, stories, and many others. No less important for now is that Instagram can be relied on for a media promotion. An example of its application is cafe promotion, which aims to help a cafe to be known by many people. The large number of Instagram users certainly provides an opportunity for business people to make the Instagram platform a social media marketing platform. The Instagram accounts of 5 Cafe Hits in Kintamani, Bali are: Montana Del Cafe Bali, Eko Bike Coffee Kintamani, Kava Kintamani, Tegu Kopi, AKASA Kintamani Coffee. The purpose of this study is to calculate the performance of Instagram accounts at 5 Cafe Hits in Kintamani, Bali. The method used for this research is exploratory quantitative method. The results of this study indicate that the Instagram account of Montana Del Cafe Bali is ranked first and has good account performance.
\end{abstract}

\begin{abstract}
ABSTRAK
Instagram merupakan salah satu media sosial yang saat ini tengah eksis dimasyarakat. Aplikasi ini dapat diunduh melalui ponsel, tablet, PC ataupun dapat dibuka secara langsung melalui website resmi instagram. Pada awal instagram diciptakan, fitur yang terdapat hanya untuk berbagi cerita berupa gambar serta mencari teman sesama instagram. Namun seiring perkembangannya, instagram sudah banyak mengalami perubahan seperti dapat menggugah video, instastory dan masih banyak lainnya. Yang tak kalah penting untuk saat ini yaitu Instagram sudah dapat diandalkan untuk sebuah media promosi. Contoh dari penerapannya yaitu promosi cafe, yang bertujuan untuk membantu sebuah cafe tersebut untuk diketahui oleh banyak orang. Banyaknya jumlah pengguna Instagram tentu memberikan peluang bagi pembisnis untuk menjadikan platform Instagram sebagai platform social media marketing. Adapun akun Instagram dari 5 Cafe Hits Di Kintamani, Bali yaitu : Montana Del Cafe Bali, Eko Bike Coffee Kintamani, Kava Kintamani, Tegu Kopi, AKASA Kintamani Coffee. Tujuan dari penelitian ini yaitu untuk menghitung kredibilitas dari performa akun Instagram pada 5 Cafe Hits Di Kintamani, Bali. Metode yang digunakan untuk penelitian ini yaitu metode eksploratif kuantitatif. Hasil dari penelitian ini menunjukan bahwa akun Instagram Montana Del Cafe Bali mendapatkan peringkat pertama dan memiliki kredibilitas performa akun yang baik.
\end{abstract}

Keyword : Credibility Account Instagram ; Social Media Instagram ; Following to Followers Ratio; 5 Cafe Hits Di Kintamani, Bali 


\section{PENDAHULUAN}

Teknologi informasi dan komunikasi yang telah berkembang pesat mampu menghantarkan manusia untuk menciptakan bentuk baru cara berkomunikasi dan berinteraksi melalui media sosial. Sarana berkomunikasi menggunakan media sosial sangat berperan dalam aktifitas keseharian bersosial di masyarakat.

Teknologi informasi dan komunikasi dirasa penting keberadaannya oleh penggunanya, dimana salah satu tujuannya adalah untuk bertukar infomasi. Keberadaan sarana komunikasi ini memberikan dampak yang signifikan di berbagai bidang seperti, sosial, ekonomi, Pendidikan dan bidang lainnya. Komunikasi tidak hanya dapat di lakukan secara fisik, tetapi juga dapat di lakukan dengan menggunakan berbagai media sosial di dunia maya. Keunggulan layanan media sosial adalah memberikan ruang komunikasi dua arah antara konsumen-perusahaan dan konsumen-konsumen. Komunikasi dua arah ini memampukan konsumen untuk berpartispasi, kolaborasi dan berinteraksi, yang pada intinya konsumen tidak lagi objek tetapi subyek pemasaran.

Dengan pesatnya perkembangan teknologi media sosial, telah memberikan dampak terhadap situs - situs komunikasi, dari yang awalnya hanya sekedar email, dan chatting, sekarang sudah banyak jejaringan media sosial yang bisa digunakan sebagai alat komunikasi. Contohnya seperti, facebook, Instagram, twitter, Telegram, Snapchat. Media sosial yang sangat diminati salah satunya adalah instagram. Instagram memiliki lebih dari 1 miliyar pengguna aktif [1]. Instagram adalah media sosial yang digunakan sebagai tempat menyebarkan dan berbagai informasi, berinteraksi dengan orang banyak, serta dapat mengenal lebih dekat dengan sesama pengguna . Instagram merupakan aplikasi berbagi foto yang memungkinkan pengguna mengambil foto, menerapkan filter digital, dan membagikannya ke berbagai layanan jejaring sosial [2].

Maraknya penggunaan Instagram membuat para peneliti ingin melakukan penilaian secara kualitatif terhadap akun - akun yang ada pada media sosial Instagram. Beberapa para peneliti telah melakukan penelitian yang terkait dengan penggunaan media sosial Instagram. Contohnya seperti penelitian Instagram sebagai media online shop dan juga sebagai media memamerkan gaya hidup atau kegiatan sehari-hari dari pemilik akun. Dalam hal ini peranan sistem informasi dalam Instagram adalah sebagai prediksi [3], [4], pendukung keputusan [5], dan keamanan [6].

Namun diantara beberapa penelitian yang sudah ada mengenai Instagram, belum ada peneliti yang meneliti tentang pencarian rasio - rasio yang dapat digunakan sebagai alat ukur dalam menilai berbagai aspek pada Instagram. Rasio - rasio ini yang nantinya dapat digunakan untuk melakukan analisa atau penelitian kuantitatif. Beberapa aspek yang dapat dinilai menggunakan rasio - rasio hasil dari penelitian tersebut yaitu, yang pertama ingetsmen yang ada pada akun Instagram tersebut, apakah ingetsmen dari akun tersebut sudah bagus atau belum. Kedua, rasio - rasio ini juga bisa digunakan untuk mengukur kredibilitas dari akun Instagram tersebut. Dan yang ketiga, untuk menilai performa dari konten atau post yang posting pada akun Instagram tersebut. (Hendika Permana 2021) 


\section{TINJAUAN PUSTAKA}

Instagram adalah aplikasi sosial media berbasis mobile untuk Android, iOS, dan Windows Phone dimana penggunanya dapat membidik, meng-edit dan mem-posting foto atau video ke halaman profil Instagram dan jejaring sosial lain terkait instagram.(DODY PERMANA 2018)

Instagram berasal dari kata "instan" atau "insta", seperti kamera polaroid yang dulu lebih dikenal dengan "foto instan" (Pengertian instagram, 2012, dalam http://.id.wikipedia.org./wiki/instagram, diakses pada tanggal 04 Januari 2016). Instagram juga dapat menampilkan foto-foto secara instan dalam tampilannya. Sedangkan untuk kata "gram" berasal dari kata "telegram", dimana cara kerja telegram adalah untuk mengirimkan informasi kepada orang lain dengan cepat. Begitu pula dengan Instagram yang dapat mengunggah foto dengan menggunakan jaringan internet, sehingga informasi yang disampaikan dapat diterima dengan cepat. Oleh karena itulah Instagram berasal dari kata "instantelegram".(Difika 2016)

Instagram merupakan suatu aplikasi sosial media yang berbasis Android untuk Smartphone, iOS untuk iPhone, Blackberry, Windows Phone dan bahkan yang terbaru saat ini juga bisa dijalankan di komputer atau PC anda. Namun untuk penggunaan di dalam komputer tidak akan bisa sama sepenuhnya dengan yang ada pada perangkat mobile phone anda.(HERMAWAN RIYADI 2019)

Instagram awalnya dikembangkan oleh startup bernama Burbn, Inc yang dimotori oleh Kevin Systrom dan Mike Krieger. Di tangan keduanya Instagram sukses membuat raksasa jejaring sosial Facebook bertekuk lutut sehingga bersedia membelinya seharga $\$ 1$ miliar, akuisisi itu terjadi pada 9 April 2012.(Bambang Winarso 2015)

Pengguna dapat menjelajahi konten pengguna lain berdasarkan tag dan lokasi dan melihat konten yang sedang tren. Pengguna dapat menyukai foto serta mengikuti pengguna lain untuk menambahkan konten mereka masuk kepada beranda.Melalui Instagram pengguna dapat mengunggah foto dan video pendek kemudian membagikannya kepada pengguna lain. Pada gambar yang diunggah, 43pengguna dapat menambahkan tag kepada orang tertentu dan penentuan lokasi. Pengguna juga dapat mengatur akun mereka sebagai "pribadi", sehingga mengharuskan mereka menyetujui setiap permintaan pengikut baru. Pengguna dapat menghubungkan akun Instagram mereka ke situs jejaring sosial lain, memungkinkan $m$ reka untuk berbagi foto yang diunggah ke situs-situs tersebut.(Fallis 2013)

Kelebihan nomer satu dari Instagram adalah anda dapat menggunakannya secara gratis. Cukup dengan mendownload aplikasi di smartphone kemudian anda dapat mendaftar akun. Anda dapat menggunakannya sepuasnya tanpa harus membayar sejumlah uang kepada Instagram.(Pahlevi 2017)

Kekurangan Instagram tidak didesain untuk e-commerce sehingga client akan sulit dalam melihat portofolio jika mengandalkan feed Instagram terutama untuk portofolio yang telah lama diposting, maka dari itu tetap membutuhkan website.(Charistia, Komunikasi, and Soetomo 2020) 


\section{METODE PENELITIAN}

Penelitian ini menggunakan metode eksploratif kuantitatif untuk mengetahui kredibilitas dari performa akun Instagram Pada 5 Cafe Hits Di Kintamani, Bali. Metode eksploratif merupakan metode yang digunakan untuk merumuskan masalah secara lebih terperinci.(Hendika Permana 2021)

Tujuan dari penelitian ini yaitu untuk mengetahui nilai kredibillitas dari performa akun Instagram Pada 5 Cafe Hits Di Kintamani, Bali. Ada beberapa langkah yang harus dilakukan dalam penelitian ini, sehingga mampu menemukan peringkat pertama akun Instagram Pada 5 Cafe Hits Di Kintamani, Bali yang memiliki performa terbaik. Langkah-langkah yang dilakukan pada penelitian ini yaitu :

\section{A. Melakukan Eksplorasi Pada Website Untuk Menentukan Objek yang Akan Dianalisa.}

Pengertian eksplorasi bisa didefinisikan sebagai sebuah kegiatan pencarian terhadap suatu hal yang baru.(Zakky 2020) Eksplorasi ini dilakukan pada beberapa halaman website yang menyediakan informasi mengenai objek yang akan di teliti. Setelah ekslorasi selesai dilakukan, sehingga ditemukan nama-nama cafe terhits di Kintamani,Bali yang akan dijadikan objek analisa. Setelah melakukan eksplorasi pada halaman website, maka langkah selanjutnya yaitu mencari nama akun Instagram dari masing-masing cafe tersebut. Pastikan semua nama cafe di Kintamani tersebut memiliki akun pada aplikasi sosial media Instagram.

\section{B. Menghitung Nilai Rata-Rata Variable 5 Cafe Hits Di Kintamani, Bali.}

Pada langkah ini, peneliti menghitung nilai Following to Followers. Variabel Penelitian adalah segala sesuatu yang berbentuk apa saja yang ditetapkan oleh peneliti untuk dipelajari sehingga diperoleh informasi tentang hal tersebut, kemudian ditarik kesimpulannya.(Mulyana 2014) Untuk menghitung nilai rata-rata dari variable following to followers yaitu dengan cara melihat jumlah followers dan following pada masing masing profil akun instagram cafe, kemudian di hitung sehingga menemukan nilai rata-rata dari masing-masing variabel.

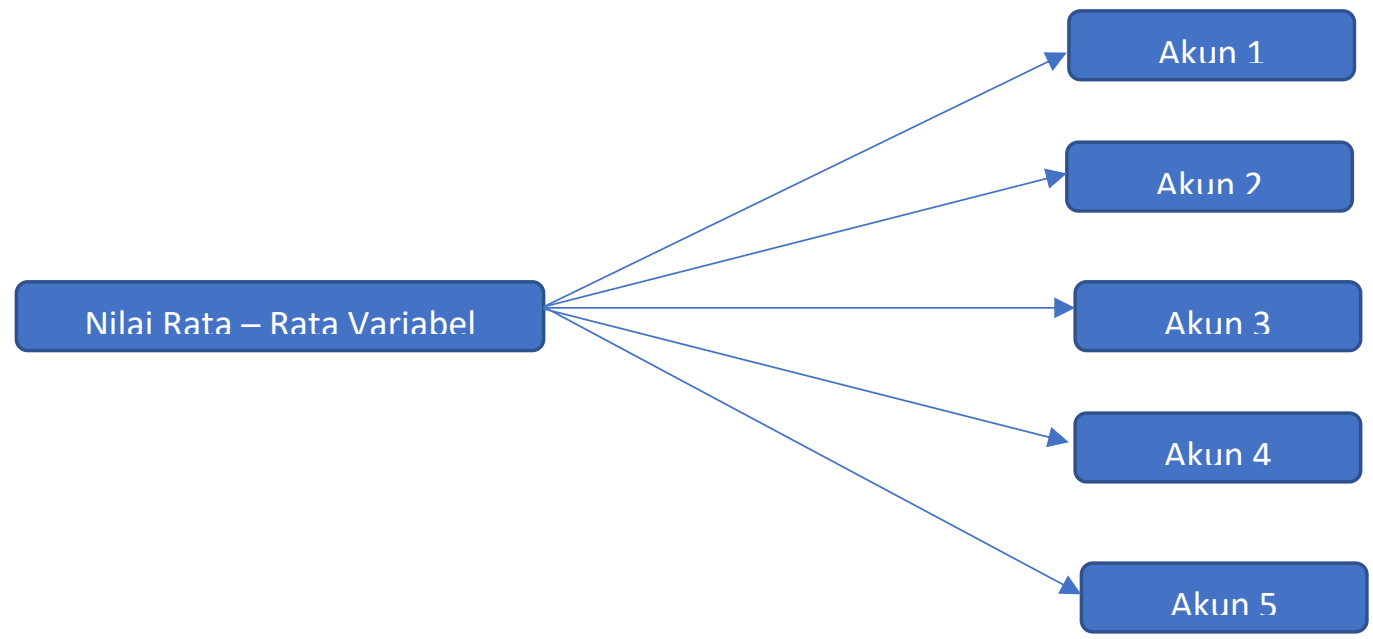

Gambar 1. Analisa nilai rata-rata variable 


\section{Menghitung Nilai Kredibilitas Rasio}

Untuk menghitung nilai kredibilitas dari following to followers, peneliti menggunakan cara membagi nilai variabel pertama dengan nilai variabel kedua. Jika akun instagram 1 memiliki 100 following dan akun instagram 2 memiliki nilai 300, maka cara menghitungnya yaitu $100: 300=0,3$. Dengan begitu nilai dari following to followers ratio adalah 0,3 .

\section{Menentukan Peringkat Pada Akun Instagram}

Pada langkah terakhir yang dilakukan pada penelitian ini yaitu menentukan peringkat pada masing-masing rasio yang ada. Pada penentuan peringkat perlu melihat karakteristik dari rasio yang di teliti. Jika karakteristik rasio merupakan rendah, maka objek yang memiliki nilai terendah akan mendapatkan angka 5 dan objek yang memiliki nilai tertinggi akan mendapatkan angka 1. Namun jika rasio memiliki karakteritik tinggi maka objek yang mendapatkan nilai tinggi akan mendapatkan angka 5 dan objek yang mendapatkan nilai terendah akan mendapatkan angka 1. Setelah mendapatkan hasil kredibilitas ratio maka dapat disimpulkan objek yang mana mendapatkan peringkat 1 sampai dengan peringkat 5

\section{Hasil Dan Pembahasan}

Akun Instagram dari 5 Cafe Hits Di Kintamani, Bali diantarnya :

\section{Montana Del Cafe Bali}

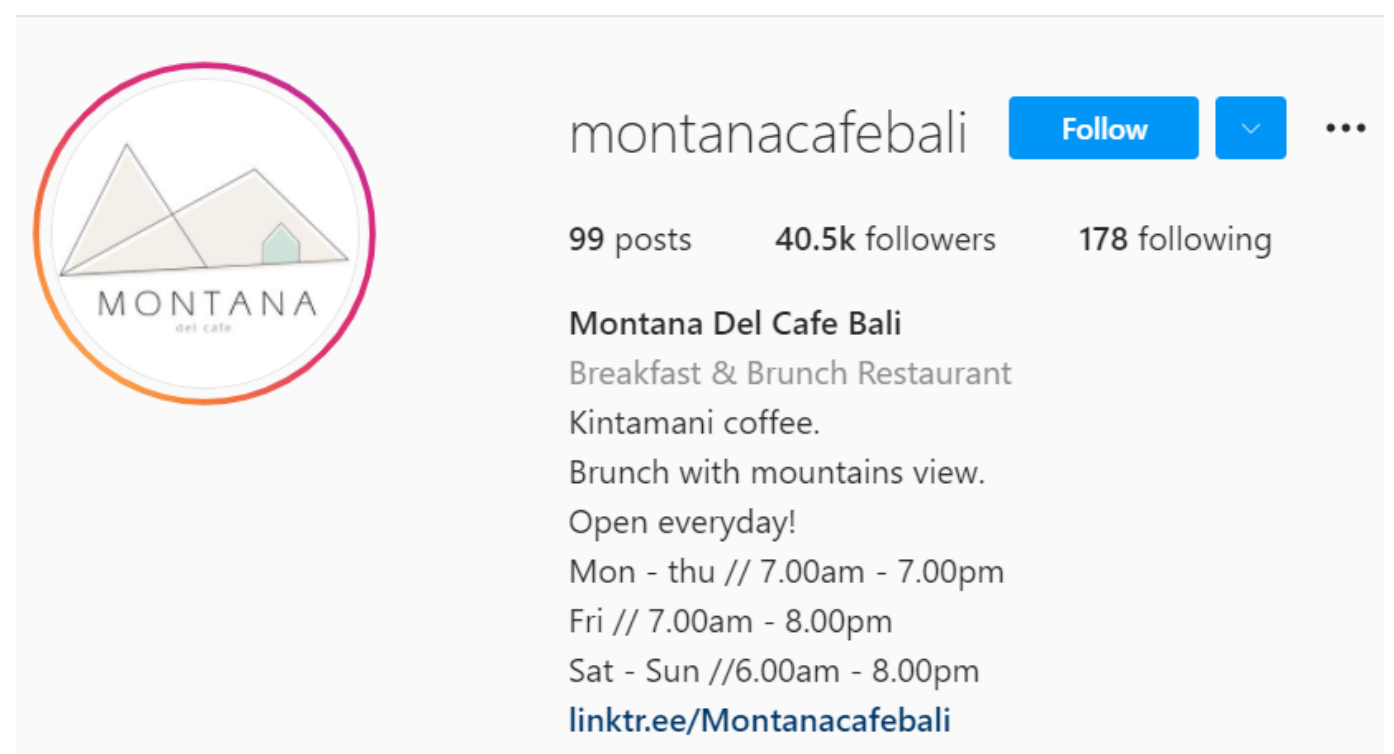

Gambar 1. Akun Instagram Montana Del Cafe Bali

Sumber : 


\section{Eko Bike Coffee Kintamani}

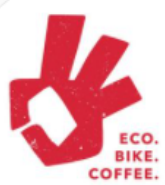

\section{kintamaniecobikecoffee Follow}

289 posts $\quad 5,100$ followers $\quad 459$ following

Eco Bike Coffee Kintamani

Coffee Shop

— Est. 2018 Roastery

Coffee shop $\cdot$ Staycation \& Bike Tour

Everyday 6am - 7pm

Ready Online Bean 087781014171

tokopedia.link/sipQBcy8Obb

Gambar 2. Akun Instagram Eko Bike Coffee Kintamani Sumber : https://www.instagram.com/kintamaniecobikecoffee/

3. Kava Kintamani

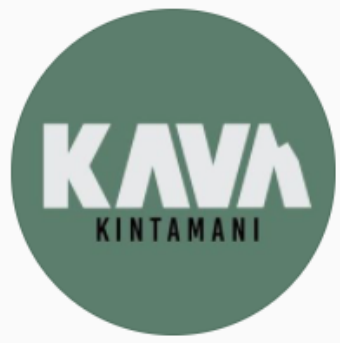

\section{kavakintamani follow}

99 posts $\quad 1,167$ followers $\quad 156$ following

KAVA KINTAMANI

Cafe

KAVA KINTAMANI COFFEE \& KITCHEN

your humble little place in Kintamani

opening hour's

- Monday-Friday(10.00-18.00)

- Saturday-Sunday(05.30-18.00)

Gambar 3. Akun Instagram Kava Kintamani

Sumber : https://www.instagram.com/kavakintamani/ 


\section{Tegu Kopi}
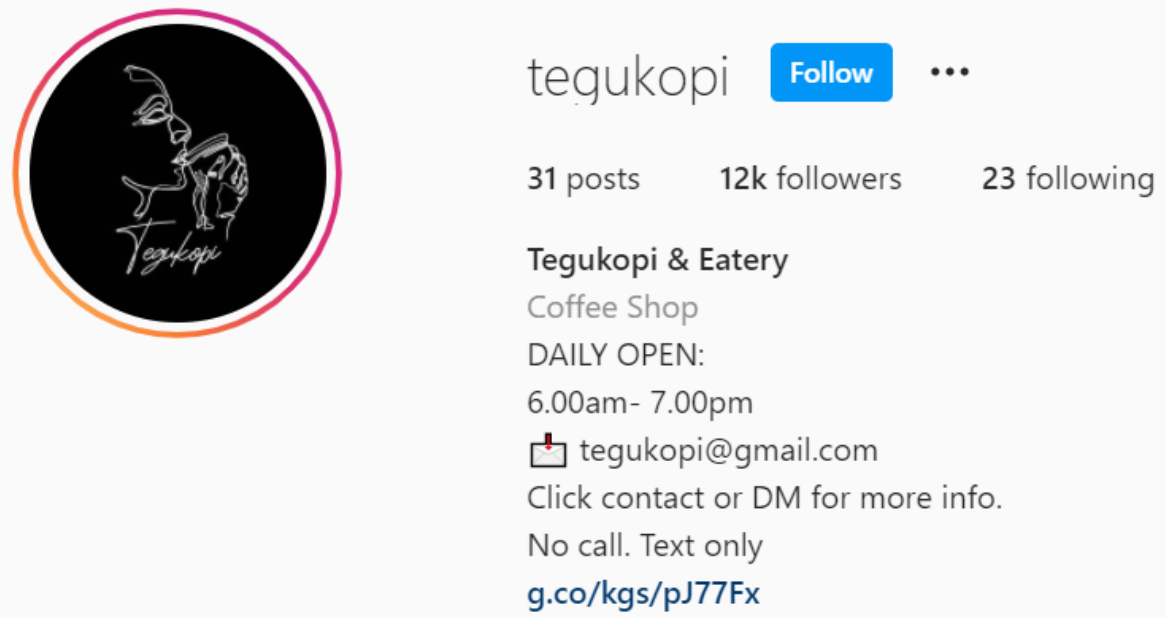

Gambar 4. Akun Instagram Tegu Kopi

Sumber : https://www.instagram.com/tegukopi/

5. AKASA Kintamani Coffee
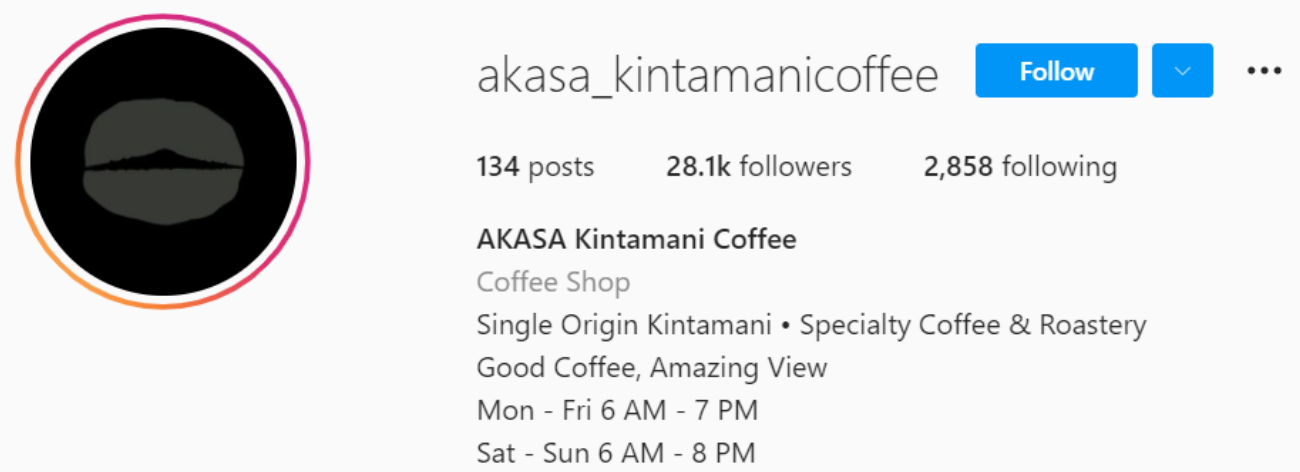

Gambar 5. Akun Instagram AKASA Kintamani Coffee Sumber: https://www.instagram.com/akasa_kintamanicoffee/

Dari kelima akun Instagram 5 Cafe Hits Di Kintamani, Bali, peneliti menemukan nilai dari masingmasing variabel yang ada untuk menghitung rasio Following to Followers dari setiap akun. Pada akun Instagram terdapat 8 variabel, diantaranya yaitu :
1. POST
2. FOLLOWING
3. FOLLOWERS
4. IMAGE LIKES
5. IMAGE COMMENTS
6. VIDEO LIKES
7. VIDEO COMMENTS
8. VIDEO VIEWS 
Dari ketujuh variabel tersebut peneliti hanya fokus untuk menemukan hasil dari 2 variabel, yaitu :

1. FOLLOWING

2. FOLLOWERS

Dari kedua variabel tersebut kemudian dianalisa sehingga menemukan nilai rata-rata dari variabel following dan variabel followers rasio. Untuk menghitung nilai rata-rata dari variabel following dan followers yaitu dengan cara melihat pada profile masing - masing akun instagram, kemudian di hitung sehingga menemukan nilai rata-rata dari masing-masing variabel. Berikut merupakan tabel nilai ratarata dari masing-masing profile akun instagram, yaitu :

Tabel 1. Analisa Nilai Rata-Rata Nilai Variabel Following to Followers Ratio Akun Instagram Montana Del Cafe Bali

\begin{tabular}{|c|c|c|}
\hline NO. & FOLLOWING & FOLLOWERS \\
\hline 1 & \multirow{10}{*}{187} & \multirow{10}{*}{39,700} \\
\hline 2 & & \\
\hline 3 & & \\
\hline 4 & & \\
\hline 5 & & \\
\hline 6 & & \\
\hline 7 & & \\
\hline 8 & & \\
\hline 9 & & \\
\hline 10 & & \\
\hline TOTAL & 187 & 39,700 \\
\hline
\end{tabular}

Sumber : Pengolah Data Excel 
Tabel 2. Analisa Nilai Rata-Rata Nilai Variabel Following to Followers Ratio Akun Instagram Eko Bike Coffee Kintamani

\begin{tabular}{|c|c|c|}
\hline NO. & FOLLOWING & FOLLOWERS \\
\hline 1 & \multirow{10}{*}{459} & \multirow{10}{*}{5,091} \\
\hline 2 & & \\
\hline 3 & & \\
\hline 4 & & \\
\hline 5 & & \\
\hline 6 & & \\
\hline 7 & & \\
\hline 8 & & \\
\hline 9 & & \\
\hline 10 & & \\
\hline TOTAL & 459 & 5,091 \\
\hline
\end{tabular}

Sumber : Pengolah Data Excel

Tabel 3. Analisa Nilai Rata-Rata Nilai Variabel Following to Followers Ratio Akun Instagram Kava Kintamani

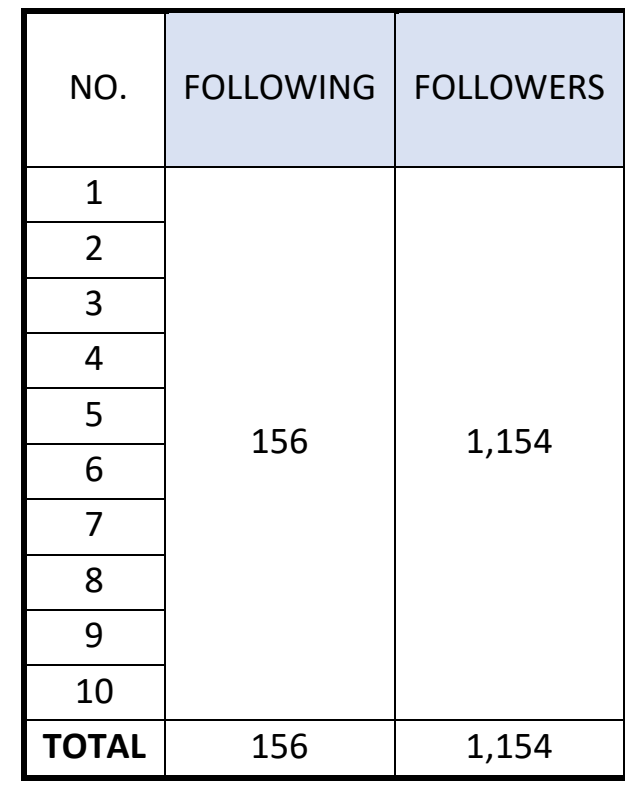

Sumber : Pengolah Data Excel 
Tabel 4. Analisa Nilai Rata-Rata Nilai Variabel Following to Followers Ratio Akun Instagram Tegu Kopi

\begin{tabular}{|c|c|c|}
\hline NO. & FOLLOWING & FOLLOWERS \\
\cline { 1 - 1 } 1 & & \\
\cline { 1 - 1 } 2 & & \\
\cline { 1 - 1 } 3 & & \\
\cline { 1 - 1 } 4 & \multirow{3}{*}{24} & \multirow{2}{*}{11,900} \\
\cline { 1 - 1 } 5 & & \\
\cline { 1 - 1 } 6 & & \\
\cline { 1 - 1 } 7 & & \\
\cline { 1 - 1 } 8 & & 11,900 \\
\hline 9 & & \\
\cline { 1 - 1 } 10 & & \\
\cline { 1 - 1 } TOTAL & 24 & \\
\cline { 1 - 1 } & & \\
\hline
\end{tabular}

Sumber : Pengolah Data Excel

Tabel 5. Analisa Nilai Rata-Rata Nilai Variabel Following to Followers Ratio Akun Instagram AKASA Kintamani Coffee

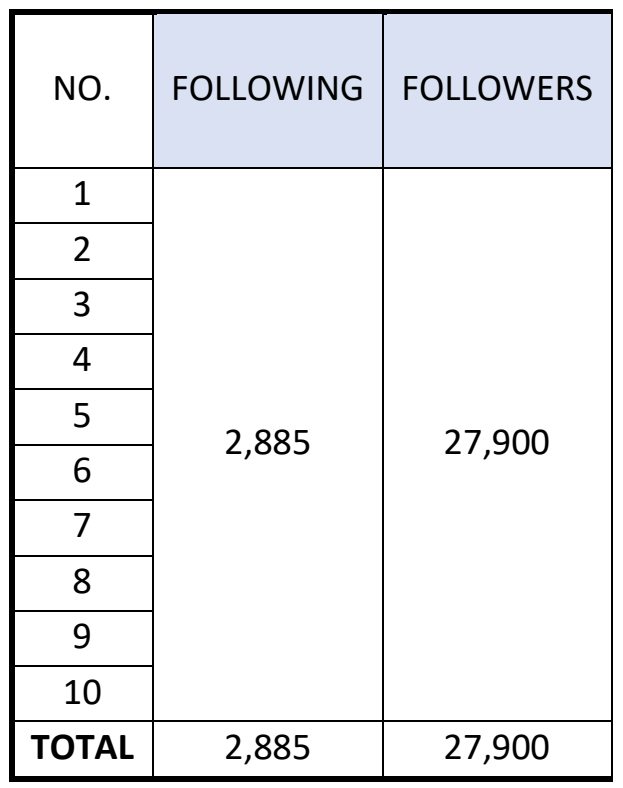

Sumber : Pengolah Data Excel 
Tabel 6. Nilai Variabel Pada Akun Instagram 5 Cafe Hits Di Kintamani, Bali

\begin{tabular}{|l|c|c|c|c|c|}
\hline Variable & Montana del Café & $\begin{array}{c}\text { Eco Bike } \\
\text { Coffee }\end{array}$ & $\begin{array}{c}\text { Kava } \\
\text { Kintamani }\end{array}$ & TeguKopi & $\begin{array}{c}\text { AKASA } \\
\text { Kintamani } \\
\text { Coffee }\end{array}$ \\
\hline Following & 187 & 459 & 156 & 24 & 2,885 \\
\hline Followers & 39,700 & 5,091 & 1,154 & 11,900 & 27,900 \\
\hline
\end{tabular}

Sumber : Pengolah Data Excel

Pada akun Instagram terdapat 14 rasio yang relevan digunakan untuk mengukur kredibilitas pada masing-masing akun. Namun pada penelitian kali ini hanya berfokus untuk menghitung Following to Followers Ratio. Untuk menghitung kredibilitas dari masing-masing akun Instagram setiap cafe, peneliti menghitung dengan cara : variabel 1 akan dibagi dengan variabel 2, sehingga ditemukan hasil analisisa dari rasio tersebut.

Tabel 7. Hasil Perhitungan Rasio Akun Instagram

\begin{tabular}{|c|c|c|c|c|c|c|}
\hline No & RATIO & $\begin{array}{c}\text { Montana } \\
\text { del Café }\end{array}$ & $\begin{array}{c}\text { Eco Bike } \\
\text { Coffee }\end{array}$ & $\begin{array}{c}\text { Kava } \\
\text { Kintamani }\end{array}$ & TeguKopi & $\begin{array}{c}\text { AKASA } \\
\text { Kintamani } \\
\text { Coffee }\end{array}$ \\
\hline 1 & $\begin{array}{c}\text { Following to Followers } \\
\text { Ratio }\end{array}$ & 0.00471033 & 0.0901591 & 0.13518198 & 0.00201681 & 0.10340502 \\
\hline
\end{tabular}

Sumber : Pengolah Data Excel

Following to Followers Ratio memiliki karakteristik yang rendah, artinya semakin rendah nilai yang dihasilkan maka semakin baik kredibilitas dari performa akun tersebut. Untuk memberikan peringkat pada masing-masing Akun Cafe, peneliti memberikan angka 5 kepada vendor yang mendapatkan nilai tertinggi dan angka 1 untuk akun cafe yang mendapatkan nilai terendah. Berikut merupakan tabel urutan nilai yang dihasilkan oleh masing-masing vendor smartphone.

Tabel 8. Nilai Variabel Pada Akun Instagram 5 Cafe Hits Di Kintamani, Bali

\begin{tabular}{|c|c|c|c|c|c|c|}
\hline No & RATIO & $\begin{array}{c}\text { Montana } \\
\text { del Café }\end{array}$ & $\begin{array}{c}\text { Eco Bike } \\
\text { Coffee }\end{array}$ & $\begin{array}{c}\text { Kava } \\
\text { Kintamani }\end{array}$ & TeguKopi & $\begin{array}{c}\text { AKASA } \\
\text { Kintamani } \\
\text { Coffee }\end{array}$ \\
\hline 3 & $\begin{array}{c}\text { Following to Followers } \\
\text { Ratio }\end{array}$ & 2 & 3 & 5 & 1 & 4 \\
\hline
\end{tabular}

Sumber : Pengolah Data Excel

Dari Tabel Nilai Rasio Akun Instagram 5 Cafe Hits Di Kintamani, Bali dapat simpulkan bahwa Cafe TeguKopi mendapatkan nilai tertinggi untuk rasio Following to Followers. Sedangkan akun Instagram Kava Kintamani mendapatkan nilai terendah untuk rasio ini. Jadi, pada penelitian ini Akun Cafe TeguKopi memiliki kredibilitas performa yang lebih baik dibandingkan dengan akun Cafe yang lainnya. 


\section{KESIMPULAN}

Tujuan dari penelitian ini adalah mengetahui kredibilitas performa dari akun Instagram 5 Cafe Hits Di Kintamani, Bali menggunakan Following to Followers Ratio. 5 Akun Cafe tersebut diantaranya : Montana Del Cafe Bali, Eko Bike Coffee Kintamani, Kava Kintamani, Tegu Kopi, AKASA Kintamani Coffee. Dari kelima akun cafe tersebut dapat disimpulkan bahwa :

1. Peringkat pertama diraih oleh akun Montana Del Cafe Bali dengan nilai tertinggi yaitu 0.00201681

2. Peringkat kedua diraih oleh akun Eko Bike Coffee Kintamani dengan nilai $\mathbf{0 . 0 0 4 7 1 0 3 3}$

3. Peringkat ketiga diraih oleh akun Kava Kintamani dengan nilai $\mathbf{0 . 0 9 0 1 5 9 1}$

4. Peringkat keempat diraih oleh akunTegu Kopi dengan nilai $\mathbf{0 . 1 3 5 1 8 1 9 8}$

5. Peringkat kelima diraih oleh akun AKASA Kintamani Coffee dengan nilai terendah yaitu 0.10340502 


\section{DAFTAR PUSTAKA}

Bambang Winarso. 2015. “Apa Itu Instagram, Fitur Dan Cara Menggunakannya? | Dailysocial.” 2015. https://dailysocial.id/post/apa-itu-instagram.

Charistia, Abigail Yuri, Fakultas Ilmu Komunikasi, and Universitas Soetomo. 2020. "Promosi Jasa Berbasis Daring Oleh Elsphotography Sub Melalui Instagram." Soetomo Communication and Humanities 1 (1): 32-45.

Difika, Fifit. 2016. "Dakwah Melalui Instagram (Studi Analisis Materi Dakwah Dalam Instagram Yusuf Mansur, Felix Siauw, Aa Gym, Arifin Ilham)." Walisongo Respository, 11-36. http://eprints.walisongo.ac.id/6462/.

DODY PERMANA. 2018. "Kelebihan Dan Kekurangan Instagram Beserta Solusinya." 2018. http://dodypermana99.blogspot.com/2018/04/kelebihan-dan-kekurangan-instagram.html.

Fallis, A.G. 2013. "Pengertian Instagram.” Journal of Chemical Information and Modeling 53 (9): 1689-99.

Hendika Permana, I Putu. 2021. "View of Analisis Rasio Pada Instagram Untuk Penelitian Kualitatif Menggunakan Metode Ekploratif."

HERMAWAN RIYADI. 2019. "Pengertian Instagram Beserta Sejarah Dan Fungsinya (Lengkap)." 2019. https://www.nesabamedia.com/pengertian-instagram/.

Mulyana, Deddy. 2014. "Metode Penelitian Metode Penelitian.” Metode Penelitian Kualitatif, 43.

Pahlevi. 2017. "Kelebihan Dan Kekurangan Instagram Sebagai Media Pemasaran Online.” 2017. https://www.pahlevi.net/kelebihan-dan-kekurangan-instagram/.

Zakky. 2020. "Pengertian Eksplorasi Menurut Para Ahli Dan Secara Umum [Lengkap]." 2020. https://www.zonareferensi.com/pengertian-eksplorasi/. 